\title{
Early mafic magmatism and crustal anatexis on the Isle of Rum: evidence from the Am Màm intrusion breccia
}

\author{
GRAEME R. NICOLL*†, MARIAN B. HOLNESS $\ddagger$, VALENTIN R. TROLL* $§$, COLIN H. \\ DONALDSON $\uparrow$, EOGHAN P. HOLOHAN*\#, C. HENRY EMELEUS** \& DAVID CHEW* \\ *Department of Geology, School of Natural Sciences, Trinity College Dublin, Dublin 2, Ireland \\ $\ddagger$ Department of Earth Sciences, University of Cambridge, Cambridge CB2 3EQ, UK \\ $\S$ Department of Earth Sciences, Uppsala Universitet, Villavägen 16, 75236 Uppsala, Sweden \\ TSchool of Geosciences, University of St. Andrews, KY16 9AL, UK \\ \#School of Geological Sciences, University College Dublin, Dublin 4, Ireland \\ ** Department of Earth Sciences, University of Durham, Durham DHI 3LE, UK
}

(Received 24 March 2008; accepted 25 September 2008; First published online 25 March 2009)

\begin{abstract}
The Rum Igneous Centre comprises two early marginal felsic complexes (the Northern Marginal Zone and the Southern Mountains Zone), along with the later central ultrabasic-basic layered intrusions. These marginal complexes represent the remnants of near-surface to eruptive felsic magmatism associated with caldera collapse, examples of which are rare in the North Atlantic Igneous Province. Rock units include intra-caldera collapse breccias, rhyolitic ignimbrite deposits and shallow-level felsic intrusions, as well the enigmatic 'Am Màm intrusion breccia'. The latter comprises a dacitic matrix enclosing lobate basaltic inclusions $(\sim 1-15 \mathrm{~cm})$ and a variety of clasts, ranging from millimetres to tens of metres in diameter. These clasts comprise Lewisian gneiss, Torridonian sandstone and coarse gabbro. Detailed re-mapping of the Am Màm intrusion breccia has shown its timing of emplacement as syn-caldera, rather than pre-caldera as previously thought. Textural analysis of entrained clasts and adjacent, uplifted country rocks has revealed their thermal metamorphism by early mafic intrusions at greater depth than their present structural position. These findings provide a window into the evolution of the early mafic magmas responsible for driving felsic magmatism on Rum. Our data help constrain some of the physical parameters of this early magma-crust interaction and place it within the geochemical evolution of the Rum Centre.
\end{abstract}

Keywords: North Atlantic Igneous Province, Isle of Rum, felsic magmas, intrusion breccia, geochemistry, magma-crust interaction.

\section{Introduction}

Establishing a major volcano on continental crust necessitates the creation of a long-lived conduit for the ascent of mantle-derived magmas to shallow crustal levels. In the early stages this will involve heating of the crust due to the accretion of mantle melts at depth. The Rum volcano displays an episode of early felsic magmatism which preceded the formation of the mafic and ultramafic layered suite (Emeleus, 1997). These early felsic magmas were largely derived from partial melting of the Lewisian gneiss basement (Dunham \& Thompson, 1967; Troll, Donaldson \& Emeleus, 2004). While there is good exposure of the felsic products (Hughes, 1960; Dunham, 1968; Williams, 1985; Emeleus 1997; Troll, Emeleus \& Donaldson, 2000), there is little direct evidence of the earliest stage of anatexis, and even less is known about the mafic body that was the presumed heat source for this crustal melting event.

Here we present evidence for early mafic intrusions that triggered anatexis and large-scale generation of felsic magmas that ultimately led to explosive

$\nmid$ Author for correspondence: g.nicoll@ed.ac.uk; current address: School of GeoSciences, University of Edinburgh, West Mains Road, Edinburgh EH9 3SW, UK. felsic volcanism on Rum. We describe enigmatic and distinctive intrusion breccias termed the Am Màm Intrusion Breccia after Am Màm hill, the type locality in the Northern Marginal Zone (Emeleus, 1997). We revise its emplacement history, and demonstrate that it entrained clasts of country-rock, gabbro and peridotite which record a pre-caldera episode of contact metamorphism and anatexis at depth. These findings shed new light on the earliest mafic magmas originally responsible for driving felsic magmatism on Rum.

\section{Geological setting}

The Isle of Rum lies on a NE-SW-trending ridge of Torridonian sandstone and Lewisian gneiss basement, and lies between Mesozoic basins to the west and east (Fig. 1). Intrusion of magma during Early Paleocene times is inferred to have caused doming at the Rum centre (cf. Emeleus, 1997). Lewisian gneiss and basal members of the Torridonian succession (the Fiachanis Gritty Sandstone and the Laimhrig Shale) inside the ring fault were uplifted, by up to $1.7 \mathrm{~km}$, and juxtaposed against much younger members of the Torridonian Applecross Formation (the Scresort Sandstone Member and the Allt Mhór na h-Uamha Member) outside the ring fault (Bailey, 1945). Subsequently, during 


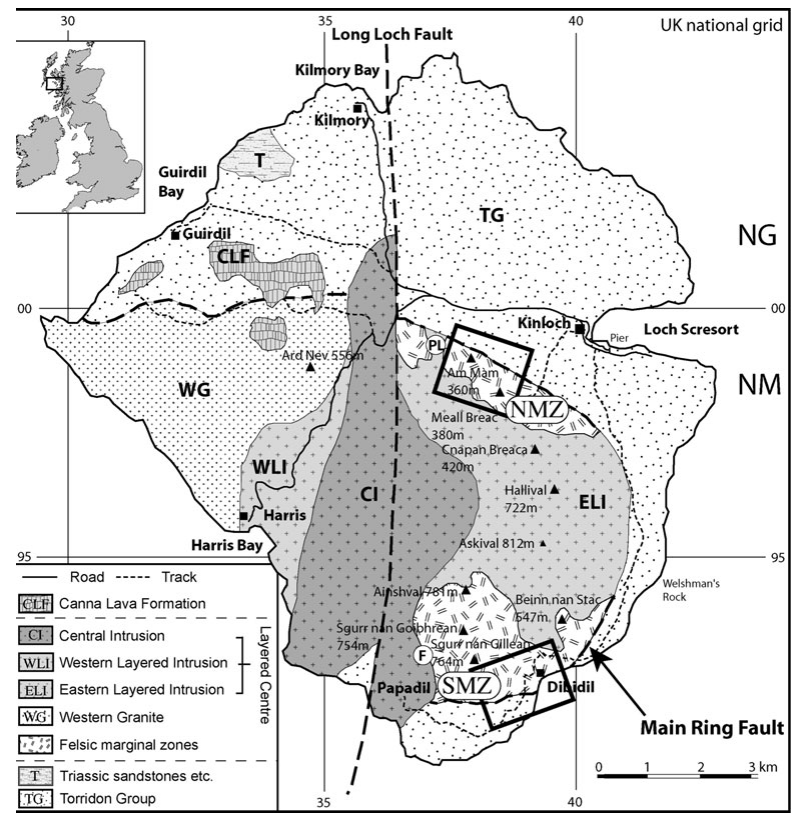

Figure 1. General geological map of the Isle of Rum showing the main components of the Paleocene igneous centre, adapted from Emeleus (1997). NMZ - Northern Marginal Zone, SMZ Southern Mountains Zone, PL - Priomh Lochs, F - Fiachanis. Black boxes indicate the area covered in the detailed geological maps in Figure 3.

the Paleocene, erosion exposed the gneiss and basal Torridonian beds at the palaeo-surface inside the ring fault. Doming was succeeded by felsic ignimbrite eruptions, caldera collapse (Emeleus, Wadsworth \& Smith, 1985; Troll, Emeleus \& Donaldson, 2000) and the intrusion of shallow-level microgranites (Black, 1954; Emeleus, 1997). Igneous activity culminated in the intrusion of a major ultrabasic magma chamber system (Harker, 1908; Wager \& Brown, 1951, 1968). Rapid sub-aerial erosion of the Rum centre followed (Emeleus, 1985; Chambers, Pringle \& Parrish, 2005), with the total duration of igneous activity at the Rum complex spanning 500000 years or less (Troll et al. 2008).

\section{Field relationships of the Am Màm intrusion breccia}

The Am Màm intrusion breccia is characterized in outcrop by a grey or cream coloured, plagioclasephyric matrix and dark mafic inclusions ranging in size from 1-10 $\mathrm{cm}$ with rounded, wispy and lobate margins (Fig. 2a), many of which have a pitted weathered surface distinct from the smoothly weathered matrix. The matrix is typically fine-grained, but is coarse in many places, with numerous euhedral phenocrysts of plagioclase (Fig. 2a, b). Some plagioclase phenocrysts show clear cores and sieve-textured rims similar to those seen in partially melted gneisses (Emeleus, 1997). Besides plagioclase feldspar, the matrix comprises minor amounts of quartz, biotite, alkali feldspar,

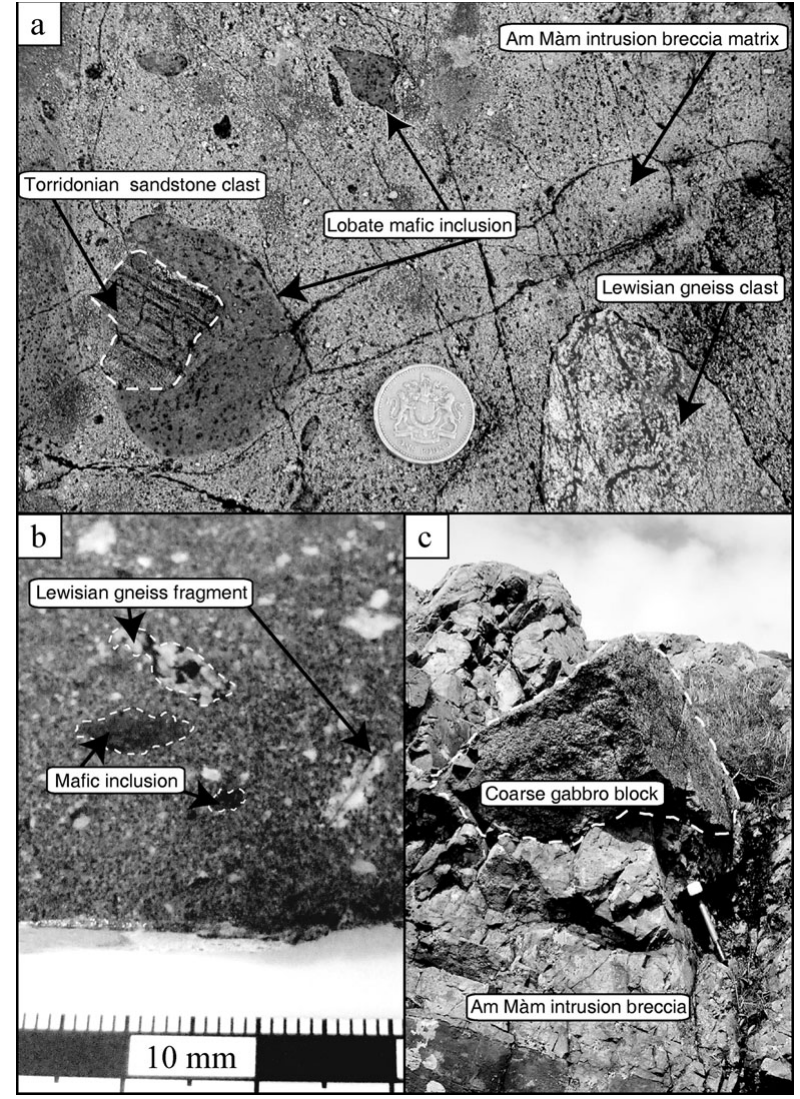

Figure 2. (a) Representative view of the Am Màm intrusion breccia matrix containing a variety of lobate inclusions as well as sedimentary and metamorphic xenoliths, Northern Marginal Zone. Coin is $2 \mathrm{~cm}$. (b) Close-up view of fine- to coarse-grained Am Màm intrusion breccia matrix from the Southern Mountains Zone; note the gneiss fragments, mafic inclusions and euhedral plagioclase feldspars. (c) Portion of Am Màm intrusion breccia with coarse gabbro blocks. Locality is close to the NE shore of Loch Gainmhich. Hammer for scale is $30 \mathrm{~cm}$ long.

opaque oxides and amphibole. Secondary calcite is common. Xenocrysts of augite occur within the matrix but are usually found close to entrained gabbro clasts.

The intrusion breccia contains rounded clasts of coarse-grained gabbro, dolerite, Torridonian sandstone and Lewisian gneiss (Fig. 2a, c). Rare clasts of feldspathic peridotite have also been recorded (Emeleus, 1997). Many of the fragments of gneiss are rounded and have granophyric rims separating quartz and feldspar crystals in thin-section. In some gneiss xenoliths, localized pockets of melt enclosed by restitic quartz contain platy quartz paramorphs after tridymite which commonly have nucleated on, and grow away from, the restitic quartz grains. There is no obvious clast alignment within the breccia, except for a weak fabric close to its margins. The clasts are matrix-supported and the breccia is poorly sorted, with a typical size range from $1 \mathrm{~cm}$ to $1 \mathrm{~m}$. Locally, the breccia contains very large (>10 m across) blocks of gneiss and gabbro. These outsized blocks are enclosed in and often intruded by intrusion breccia matrix (Figs 2c, 3). 

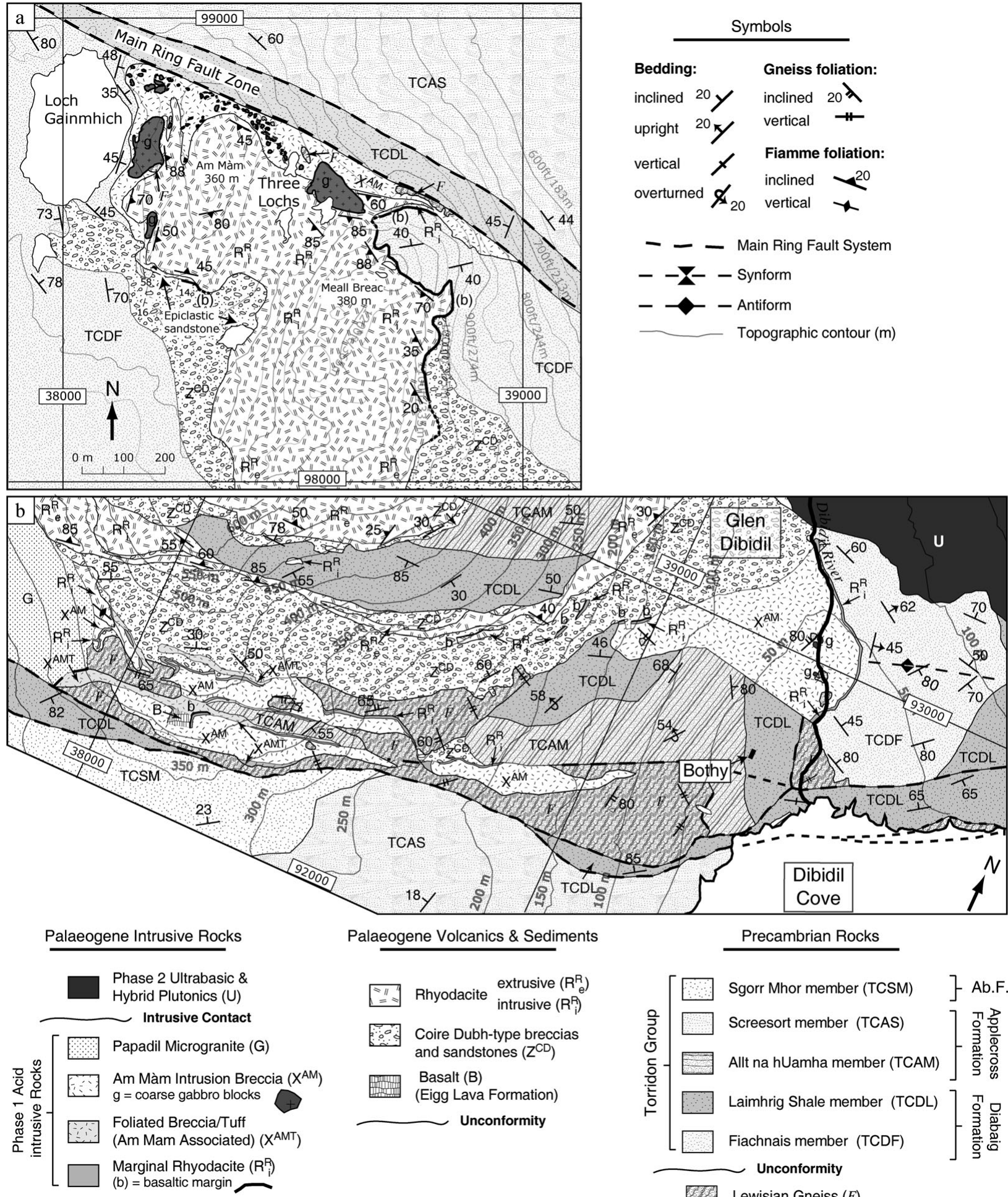

Palaeogene Volcanics \& Sediments

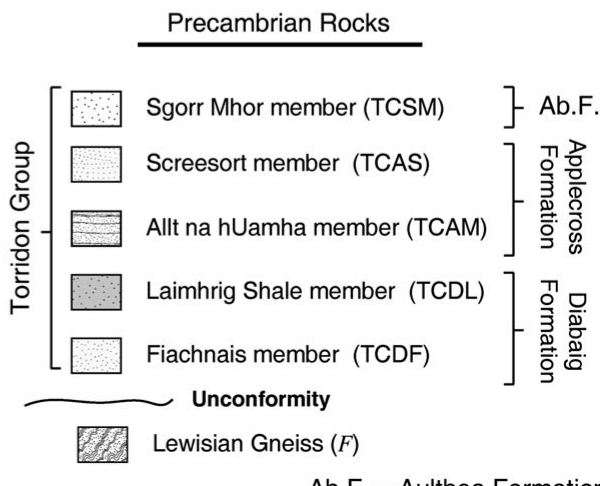

Ab.F. $=$ Aultbea Formation

Figure 3. (a) Geological map of the main area of Am Màm intrusion breccia west of Loch Gainmhich, Northern Marginal Zone. (b) Geological map of the Am Màm intrusion breccia, Southern Marginal Zone; also see Holohan et al. (2009, this issue). UK national grid system letters NM, $1 \mathrm{~km}$ grid square shown; both maps are the same scale.

\section{3.a. Northern Marginal Zone}

Within the Northern Marginal Zone, the main mass of the intrusion breccia makes up the northern and western sides of Am Màm hill, but also continues round the northern side of Meall Breac (Figs 1, 3a). The northern boundary is in faulted contact with the Torridonian
Laimhrig Shale Member outside the inner Main Ring Fault (Fig. 3a). The Am Màm Intrusion Breccia also intrudes a large body of Lewisian gneiss [NM 38750 98621] that forms the prominent break in slope on the north end of Meall Breac. The contact is gradational to sharp with signs of partial melting of the gneiss. The western and eastern contacts, along the eastern side of 


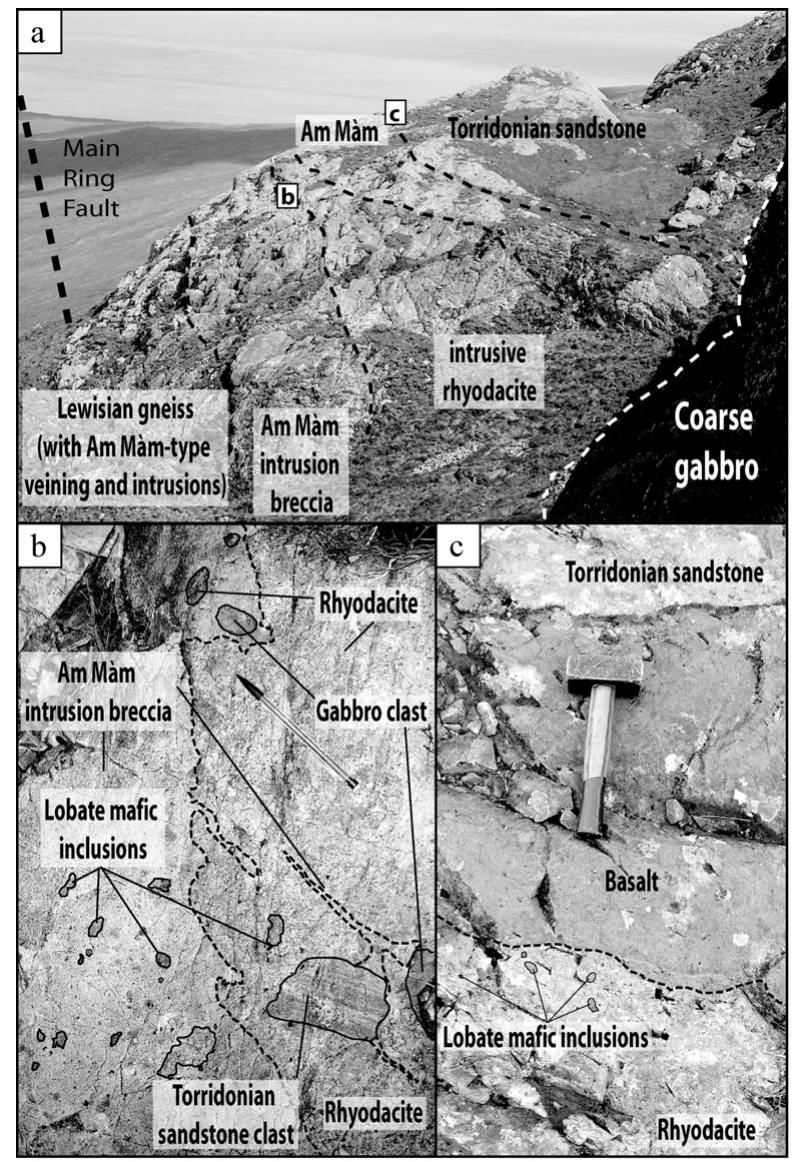

Figure 4. (a) View looking east of the intrusive rhyodacite and Am Màm intrusion breccia, showing a steep inward inclination, intruding into Lewisian gneiss and Torridonian sediments, north of Meall Breac, Northern Marginal Zone. (b) Close-up of Am Màm veins or streaks in the rhyodacite, with rhyodacite inclusions also within the Am Màm and the transfer of a Torridonian sandstone and gabbro clasts from the Am Màm to the rhyodacite. (c) View of the chilled outer basaltic margin contact to the Torridonian, which is lacking against the inner rhyodacite contact.

Loch Gainmhich and on the northern slopes of Meall Breac, juxtapose the Am Màm breccia and sandstones and siltstones of the Torridonian Diabaig Formation (Fig. 3a). These contacts dip $45-60^{\circ} \mathrm{E}$ or $\mathrm{S}$ towards the centre of the island and are marked by previously unrecognized dolerite/basalt and/or rhyodacite margins (Fig. 3a). These marginal facies and the contacts of the intrusion breccia are best observed at [NM 38750 98600] north of Meall Breac (Figs 3a, 4a). Here, a finegrained $\sim 50 \mathrm{~cm}$ thick mafic zone is locally present at the contact with folded and deformed Torridonian siltstones [NM 38811 98560] (Fig. 4a). This mafic zone dips $50-60^{\circ}$ to the south, with a well-developed and prominent chilled margin against the Torridonian sediments (Fig. 4a, c). A $\sim 30 \mathrm{~cm}$ thick porphyritic rhyodacite occurs on the inner side of this mafic zone. It contains $1 \mathrm{~mm}$ phenocrysts of euhedral plagioclase and rare quartz within a fine-grained, dark blue-grey matrix. The contact of the rhyodacite zone against the outer basaltic zone is sharp to lobate, but unchilled (Fig. 4c). The rhyodacite and the Am Màm intrusion breccia proper have a gradational contact over $40 \mathrm{~cm}$, with evidence of partial mixing between the two.

A large rhyodacite dyke which dips $60^{\circ} \mathrm{S}$ with a strong foliation parallel to its margins occurs within the intrusion breccia north of Meall Breac (Figs 3a, 4a) (Emeleus, 1997; Troll, Emeleus \& Donaldson, 2000). The contact between the grey/lilac rhyodacite and the beige/cream Am Màm matrix is characterized by: (1) inclusions of Am Màm matrix within the rhyodacite and vice versa (Fig. 4b); (2) lobate contacts and no visible chilling of either rock type; (3) mafic inclusions throughout both rock types; and (4) apparent transfer of phenocrysts and lithic clasts from the $\mathrm{Am}$ Màm to the rhyodacite and vice versa. These relationships, suggestive of mingling, highlight a close and previously unconsidered temporal connection between the emplacement of the Am Màm intrusion breccia and that of the porphyritic rhyodacite.

The basaltic and rhyodacitic margins are not present at all localities. For example, they disappear at the eastern tail of the Am Màm intrusion northeast of Meall Breac (Fig. 3a). However, where the basaltic margin is absent there is generally an increase in the number of mafic inclusions within the matrix. A basaltic margin, very similar in character to that described above, is also present at the contact between the Torridonian siltstones and the large intrusive rhyodacite body [NM 38700 98500] that makes up the majority of Meall Breac (Troll, Donaldson \& Emeleus, 2004). Indeed, this basaltic margin can be traced around the Torridonian sediments to meet the mafic margin of the Am Màm breccia north of Meall Breac (Figs 3a, Figs 4a). Moreover, the foliated rhyodacite dyke within the Am Màm breccia (Fig. 4a) is also connected to this main intrusive rhyodacite body (Emeleus, 1997).

A few hundred metres to the west at Three Lochs [NM 38538 98641], a large $250 \mathrm{~m}$ block of gabbro is in contact the Am Màm intrusion breccia (Fig. 3a). The contacts of the Am Màm matrix are chilled against the overlying gabbro but are lobate against the underlying rhyodacite. Similar sharp, but unchilled, contact relationships with the rhyodacite can be traced in detail around the Am Màm intrusion breccia, along the northern side of Am Màm hill [NM 3845 9875] and along the eastern side of Loch Gainmhich (Fig. 3a).

At the southern end of Am Màm hill [NM 38220 98449], the coeval nature of the Am Màm intrusion matrix and the rhyodacite sheets is also evident. Here, sedimentary Coire Dubh breccia and intracaldera 'epiclastic' sandstone (Emeleus, 1997; Brown, Holohan \& Bell, 2009, this issue) are intruded at high angles $\left(\sim 45^{\circ} \mathrm{NE}\right)$ by rhyodacite with basaltic margins (Figs 3a, 5). The epiclastic sandstone and the Coire Dubh breccia have been baked where they are in contact with the sharply chilled basalt. A $<1 \mathrm{~m}$ zone of Am Màm intrusion breccia occurs between the basaltic margin and the main mass of rhyodacite (Fig. 5) and joins to the main mass of intrusion breccia to the northwest (see Fig. 3a). Neither the Am Màm material 


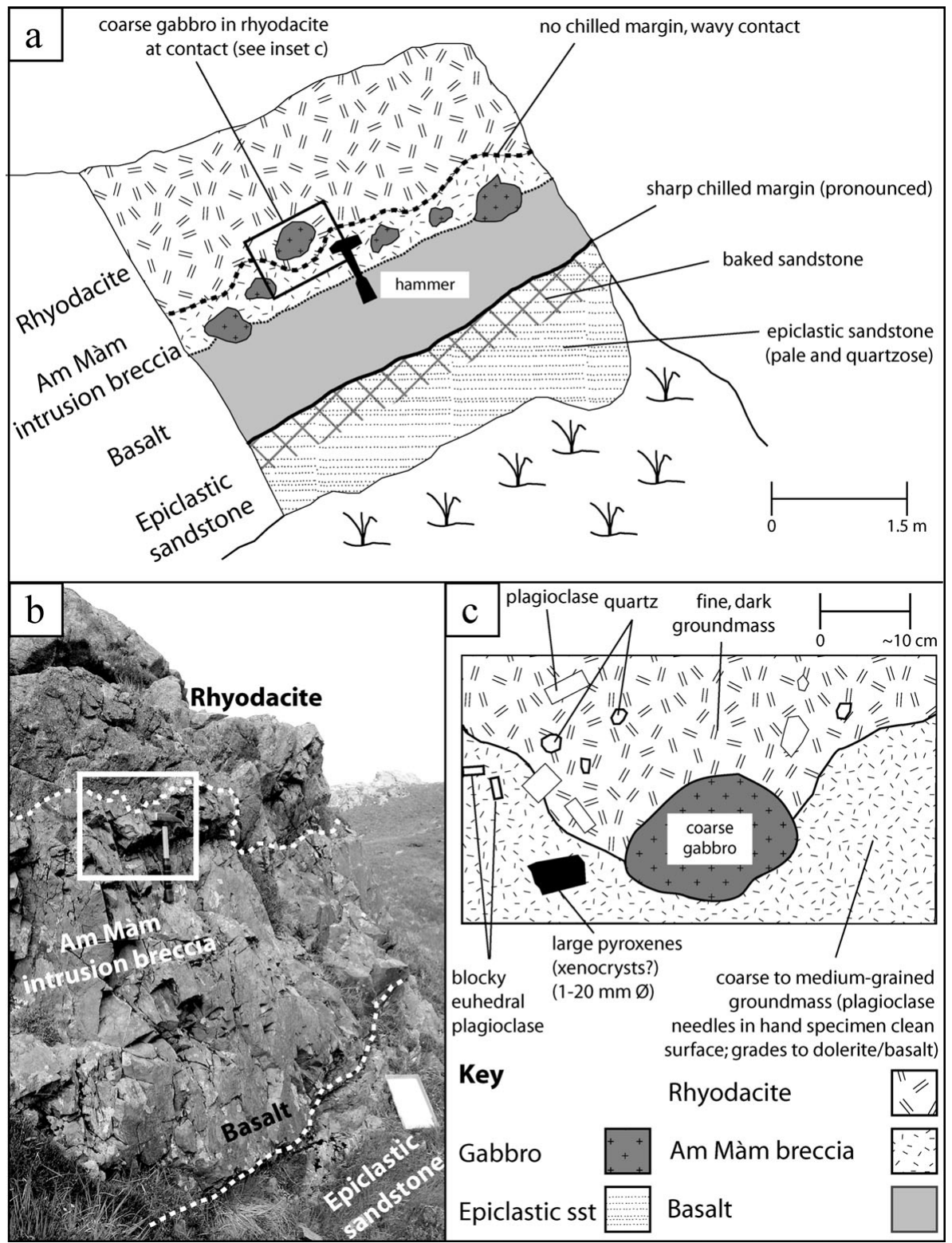

Figure 5. Contact relationships between grey/lilac intrusive rhyodacite and beige to creamy coloured Am Màm matrix, in outcrop at the southern end of Am Màm hill, Northern Marginal Zone. (a) Sketch of the contact relationships observed. Note the wavy gradational contact between the rhyodacite and Am Màm-type material, which grades into basalt. There is a prominent chilled margin to the basalt and a zone of baking in the country rock epiclastic sandstone. (b) Photo of the outcrop looking east, hammer for scale on the rhyodacite contact with Am Màm-type material. Notebook is on the epiclastic sandstone, bottom right. Intrusive basaltic contact dips $\sim 45^{\circ}$ to the north. (c) Sketch of the area highlighted in (b) by the white square. Note the apparent transfer of crystals between the two rock types and the presence of a coarse gabbro clast in the process of transfer between the two.

nor the rhyodacite show contact chilling (Fig. 5), and phenocryst and lithic (gabbro) clast transfer between the two is inferred (Fig. 5c).

\section{3.b. Southern Mountain Zone}

Rocks previously mapped as intrusive tuffs and tuffisites occur along the Main Ring Fault system in the Southern Mountains Zone (Hughes, 1960; Emeleus, 1997). These rocks show a grey to creamy, fragmental to crystalline matrix that contains euhedral crystals of plagioclase and numerous lobate and fine-grained mafic inclusions $(1-6 \mathrm{~cm}$ in diameter). The matrix envelops clasts of sandstone, dolerite, gabbro and gneiss that are up to several metres in diameter. In addition to these lithological features, the internal structure, stratigraphic and structural position, petrography, geochemistry and timing of emplacement of these rocks (discussed in Sections 3.b and 7.a) are all very similar to those of the Am Màm intrusion breccia of the Northern Marginal Zone. We thus reclassify these intrusive rocks of the Southern Mountain Zone as 'Am Màm-type breccias' (see also Holohan et al. 2009, this issue) and shall collectively refer to them as the Am Màm intrusion breccia.

There are five discrete outcrops of Am Màmtype intrusion breccia along the Main Ring Fault of the Southern Mountains Zone (Fig. 3b). The largest 
outcrop occupies lowland along and to the southwest of the Dibidil River (see also fig. 3 in Holohan et al. 2009 , this issue), which locally follows the northeastern boundary of the intrusion. The Am Màm breccias here abut against Torridonian sandstones, and intrude and surround several discrete bodies of Lewisian gneiss and gabbro. Thin $(\sim 0.5-1 \mathrm{~m})$ intrusive rhyodacite bodies with abundant lobate mafic inclusions occur in the Am Màm breccia along the course of the Dibidil River as a series of low outcrops. It is generally unclear if the rhyodacite intrudes the breccia or vice versa, due to an absence of chilling. On the eastern side of the Dibidil River [NM 39435 92925], however, a NEdipping rhyodacite dyke is chilled against Torridonian sandstone, but grades westwards into the Am Màm intrusive breccia matrix. On the western side of the river [NM 39408 92946], along-strike of this rhyodacitesandstone contact, there is a similar westward transition from rhyodacite to intrusive breccia matrix. It thus seems that rhyodacite locally forms the northeast margin to this Am Màm intrusion breccia outcrop.

Rhyodacite and/or basalt can also be locally observed along the northwest margin of this intrusion breccia outcrop, where reddish, arkose-dominated Coire Dubhtype breccia forms the country rock (Fig. 3b). The contact is exposed at [NM 38993 92940], where it dips at $50^{\circ} \mathrm{NW}$. Here, moderately crushed sedimentaryderived Corrie Dubh-type breccia (see Holohan et al. 2009 , this issue) overlies a $1-2 \mathrm{~cm}$ thick, dark-grey zone with a fine-grained matrix and scattered plagioclase phenocrysts. This outer dark-grey mafic zone delimits the intrusive breccia, which displays strongly contact-parallel aligned mafic inclusions. Moreover, neither the dark-grey zone nor the intrusion breccia shows any signs of crushing. These relationships demonstrate that the Am Màm intrusion breccia postdates the Coire Dubh-type breccia (Fig. 6a).

The rhyodacite/basalt marginal facies are best exposed around the westernmost outcrops on the southsoutheast slopes of Sgurr nan Gillean (Fig. 3b). Locally present is a third type of marginal facies, referred to here as 'foliated breccia/tuff facies' of the Am Màm intrusion breccia, ( $\mathrm{X}^{\mathrm{AMT}}$ on Fig. 3b). This facies is seen at [NM 38255 92453], where light-grey Am Màmtype material with a strong, contact-parallel foliation intrudes dark-red arkose-rich Coire Dubh-type breccia (Fig. 6a). Between this foliated outer facies and more typical Am Màm-type breccia matrix are exposures of rhyodacite. The contact of the rhyodacite with the Am Màm intrusion breccia matrix is diffuse or shows evidence of intimate intermingling. At [NM 38074 92415], rhyodacite and Am Màm breccia can be seen to respectively form the margins and core of a composite sheet which protruded into the Coire Dubhtype breccia. The rhyodacite is chilled only against the sedimentary breccia (Fig. 6b).

The margin to the Am Màm-type intrusion is locally marked by a dark fine-grained basaltic margin up to $1 \mathrm{~m}$ thick (Fig. 6a, b). Rhyodacite is generally present on the inside of this mafic margin. The contact between the

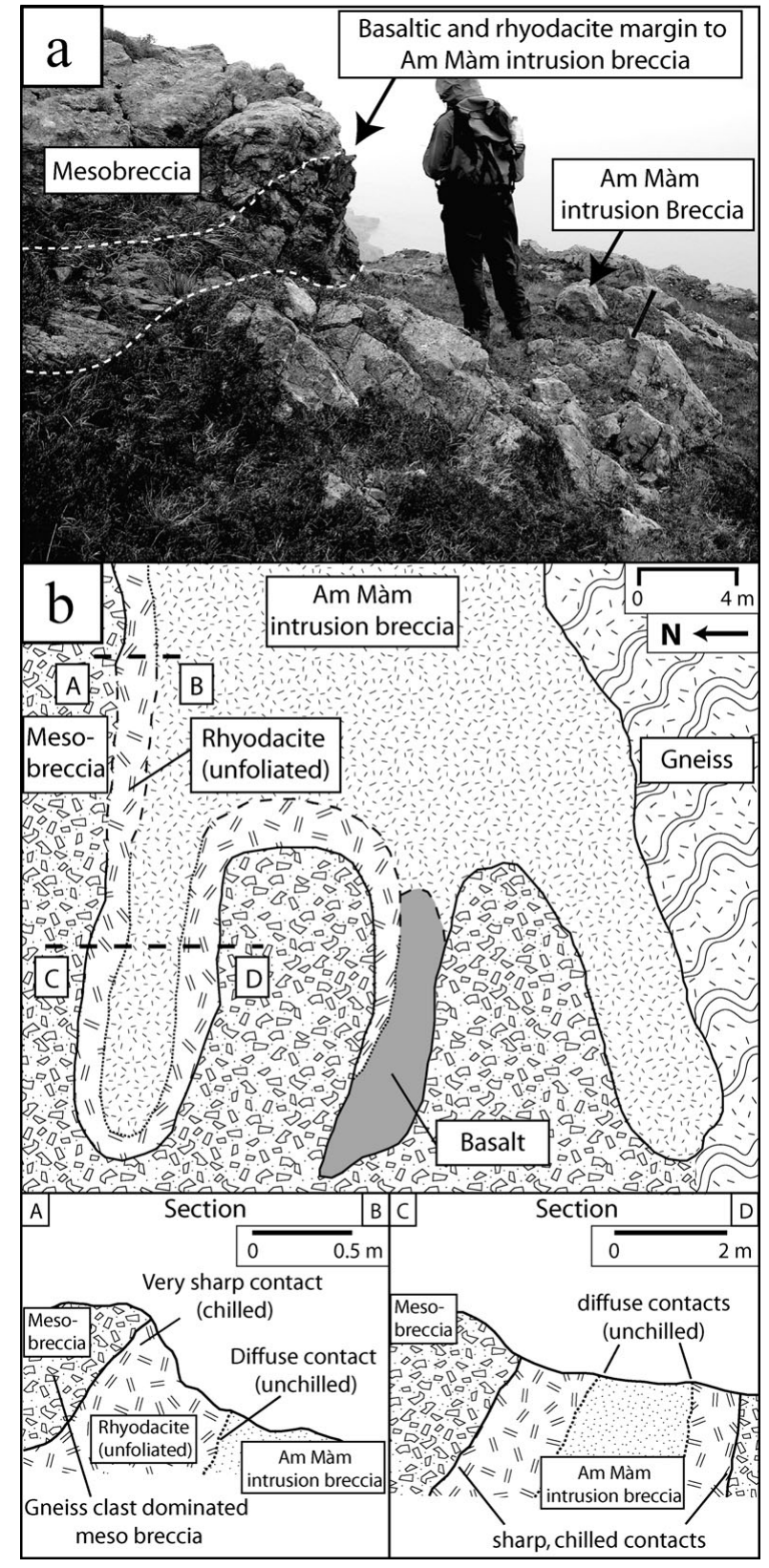

Figure 6. (a) Margin of the Am Màm intrusion breccia on the southern slope of Sgurr nan Gillean, Southern Mountains Zone, showing a basaltic and porphyritic rhyodacite margin chilled against, and intruding into, sedimentary derived breccia. (b) Plan sketch map of the relationship between intrusive Am Màm breccia with porphyritic rhyodacite margins, and gneiss-dominated mesobreccia. South side of Sgurr nan Gillean, Southern Mountains Zone [NM 38074 92415]. A-B and C-D are cross-sections through this margin.

two is sharp, but clear indication of chilling is usually absent. Locally, for instance at [NM 3818 9233], intricate, unchilled contacts and colour gradation point to mingling, and even partial mixing, of rhyodacite and basalt. In general, rhyodacite \pm basalt margins to the Am Màm intrusion breccia are observed at contacts with Coire Dubh-type sedimentary breccia and Torridonian rocks, but very rarely against the gneiss. One example of the latter occurs at [NM 38511 92482] (see Fig. 3b), where gneiss has been partially 
melted and has taken on a granophyric appearance. The westernmost outcrop of Am Màm intrusion breccia (Fig. 3b) displays a basalt-rhyodacite margin, but also seems to have a steeply inclined core of foliated rhyodacite, like that seen north of Meall Breac in the Northern Marginal Zone (Fig. 3a).

In agreement with Hughes (1960), our mapping also suggests that the internal foliation and contacts of the Am Màm intrusion breccia are in turn cut by, and thus pre-date, the Papadil Granophyre. Along the trace of the inner strand of the Main Ring Fault system, where the foliated breccia/tuff facies primarily occurs, the Am Màm intrusion breccia is unbroken. In contrast, both the Am Màm intrusion breccia and the Papadil Granophyre are brecciated along the outer strand of the Main Ring Fault system.

\section{Coarse gabbro and gneiss within the intrusion breccia}

The coarse gabbro clasts occur throughout the Am Màm intrusion breccia (Fig. 2) in the Northern Marginal Zone (Fig. 3a). Fewer and smaller gabbro clasts occur in the Southern Mountains Zone (Fig. 3b). The gabbro contains two pyroxenes, coarse cumulus plagioclase with primary $\mathrm{Fe}$-Ti oxides and very little olivine. In general, these gabbro clasts are rounded to sub-angular. All maintain their coarse-grained character throughout, with no indication of chilling against the Am Màm matrix.

At [NM 38223 98722] east of Loch Gainmhich, a composite mega-block, enclosed by the Am Màm intrusion breccia, comprises coarse, crudely laminated gabbro block $(70 \times 150 \mathrm{~m})$ with an intrusive contact against Lewisian gneiss (Fig. 3a). The Lewisian gneiss far from the intrusive contact with the gabbro is composed of coarse-grained banded amphibolite and highly altered biotite quartzo-feldspathic gneiss, with abundant evidence of partial melting involving quartz and feldspar (see Fig. 7a, b). Textures inferred to have resulted from the solidification of partial melt include the development of well-equilibrated 'string-ofbeads' textures along quartz-feldspar grain boundaries (Fig. 7b). Larger melt pools solidified to form euhedral crystals of feldspar or faceted overgrowths of adjacent restitic feldspar enclosed by quartz oikocrysts (Fig. 7c, d).

Close to the contact with the gabbro, evidence for reaction of biotite to orthopyroxene + melt is provided by abundant rounded, sub-equant clots of sheet silicates surrounding chloritized relicts of biotite grains. We interpret these clots to be pseudomorphs after orthopyroxene. At the contact, the Lewisian gneiss comprises sieve-textured rounded grains of restitic feldspar together with pseudomorphs after orthopyroxene, set in a fine groundmass of euhedral, randomly oriented, plagioclase grains with interstitial quartz. Irregular elongate patches rich in ilmenite are the probable sites of completely reacted original biotite grains.
The gabbro itself has a well-developed chilled margin with grain sizes of $\sim 1 \mathrm{~mm}$ up to $1.5 \mathrm{~m}$ away from the contact with the Lewisian gneiss, while $10 \mathrm{~m}$ from the contact the grain size is consistently $>5 \mathrm{~mm}$. The gabbro contains euhedral, randomly oriented laths of plagioclase (generally normally zoned, with cores of $\mathrm{An}_{46-48}$ and rims of $\mathrm{An}_{51-57}$ ), abundant $\mathrm{Fe}$ Ti oxide grains, clinopyroxene and euhedral apatite, together with rare, completely replaced grains that were probably originally olivine (Fig. 7e). Within a few metres of the contact, the gabbro is rich in orthopyroxene, and contains granophyre-filled pockets interstitial to the euhedral plagioclase laths, indicative of contamination by the adjacent partially melted gneiss. The gabbro within the fine-grained chilled zone adjacent to the Lewisian gneiss, contains brecciated seams with cataclastic deformation.

Although the gabbro is generally highly altered, with poorly visible clinopyroxene-plagioclase grain boundaries, a population of 30 clinopyroxene-plagioclaseplagioclase dihedral angles (see example in Fig. 7f) was measured in a sample $1.4 \mathrm{~m}$ from the contact (within the relatively fine-grained chilled zone). The median of this population is $109^{\circ}$.

\section{Minor intrusions along the Main Ring Fault}

In addition to the Am Màm intrusion breccias already described, several smaller bodies of felsic intrusive rock occur along the course of the Main Ring Fault. These outcrops are noteworthy because of their association with high-grade metamorphosed Torridonian and Lewisian rocks and the presence of abundant gneissic and ultrabasic xenoliths. The presence of cross-cutting chilled mafic dykes and the likelihood that these bodies are fault-bounded suggest that these outcrops belong to an early phase of activity (cf. Emeleus, 1997).

Several small $\left(1 \mathrm{~m}^{2}\right)$, low-lying exposures of partially melted Lewisian gneiss, Torridonian siltstone and intermediate, medium-grained, non-foliated igneous rock form linear clusters north of Coire Dubh in the Northern Marginal Zone at [NM 3947 9830] and [NM 39442 98368]. The igneous rock contains abundant xenoliths $(1-5 \mathrm{~cm}$ in diameter) of partially melted Lewisian gneiss, together with abundant normally zoned phenocrysts of plagioclase with elongate, altered clinopyroxene prisms within a feldspar and quartzrich matrix. Solidified melt in the Lewisian clasts comprises fine-grained granophyric intergrowths, with rare quartz paramorphs after tridymite in enclosed, melt-bearing, fractures. The Lewisian gneiss xenoliths contain abundant millimetre-scale shear zones, and evidence that deformation began at high temperatures is provided by folded dendritic outgrowths of the plagioclase grains.

The metamorphic grade of the Torridonian siltstone associated with these outcrops is generally much higher than that of the surrounding Torridonian. While the former is commonly spherulitic, indicating partial melting, the latter still contains microcline, 


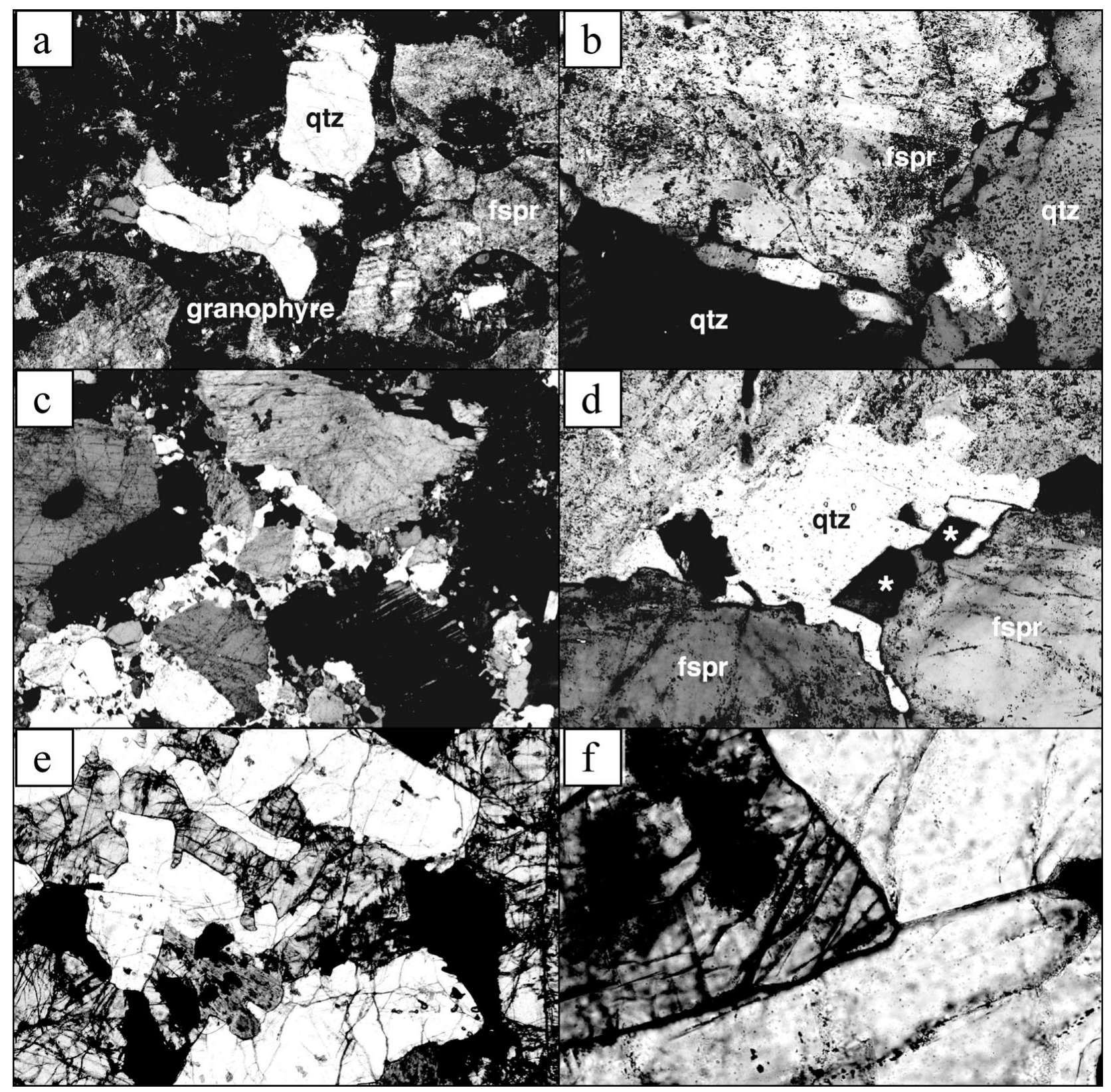

Figure 7. (a) Xenolith of Lewisian gneiss entrained in the Am Màm breccia, showing rounded restitic grains of quartz and feldspar separated by parallel-sided seams of fine granophyre. Image is $4.5 \mathrm{~mm}$ across. (b) Lewisian gneiss from the large block entrained in the Am Màm breccia (sample 51553). Grain boundaries between quartz and feldspar are filled with small grains interpreted as formed from solidifying melt (the 'string-of-beads' texture). Other grain boundaries are highly convoluted due to incipient granophyre formation. Image is $1 \mathrm{~mm}$ across. (c) Sample 51553 showing textures developed from the solidification of large melt pools. Note the clusters of well-formed feldspar grains set in oikocrystic quartz forming fine-grained polycrystalline seams separating large restitic grains. Image is $4.5 \mathrm{~mm}$ across. (d) Sample 51553 showing euhedral overgrowths (marked by asterisks) on restitic feldspar, enclosed by oikocrystic quartz. Image is $1 \mathrm{~mm}$ across. (e) Gabbro from the chilled margin $1.4 \mathrm{~m}$ from the contact with the Lewisian at Loch Gainmhich, Northern Marginal Zone. Image is $4.5 \mathrm{~mm}$ across. (f) Clinopyroxene-plagioclase-plagioclase junction displaying a dihedral angle of $96^{\circ}$ which, although lower than the median of the measured population, is clearly higher than the original impingement angle. Note the change in curvature at the junction itself, indicative of sub-solidus textural maturation. See text for details. Image is $0.45 \mathrm{~mm}$ across.

consistent with a location outside the microcline-out isograd of the aureole associated with the main Rum Igneous Complex (Holness \& Isherwood, 2003). This demonstrates that these small exposures belong to discrete, fault-bounded, blocks of high-grade rocks emplaced into lower-grade rocks at a higher structural level. The high metamorphic grade of the faultbounded block (or blocks) therefore records a prefaulting period of heating at depth.
Just north of Loch Gainmhich (Figs 2, (Figs 3a), numerous small outcrops of fine-grained, commonly highly altered, dolerite occur. The dolerite is cut by thin basaltic dykes (some of which lack chilled margins) and contains numerous xenoliths of Lewisian gneiss. Locally, partially melted Torridonian xenoliths and gabbroic crystal clots are present. The Lewisian gneiss xenoliths are generally centimetre-scale and rounded, but may also be angular and up to $1 \mathrm{~m}$ across. In some 
places, almost completely assimilated gneiss forms plagioclase-rich patches in the dolerite. Fine-grained granophyric rims separate original quartz-plagioclase grains, and quartz paramorphs after tridymite occur in solidified melt patches within original quartz-rich regions.

In the Southern Mountain Zone, a $200 \times 50$ m faultbounded (and locally heavily brecciated) 'whaleback' of Lewisian gneiss (see fig. 3 in Holohan et al. 2009 , this issue) occurs in the lower SE slopes of Beinn nan Stac, with steep to vertical $\left(160 / 80^{\circ} \mathrm{SW}\right)$ gneissic banding. Its southern end is in contact with an intrusive body of porphyritic rhyodacite. The amphibolite-facies assemblages in this Lewisian block have been extensively overprinted. At the northern end of the outcrop, original biotite and hornblende are heavily chloritized, and the gneisses contain pockets of epidote, chlorite and actinolite set in albite, suggestive of extensive hydrothermal alteration at greenschist-facies conditions. Epidote-filled veins are common throughout the gneiss block, and feldspar is invariably highly turbid. Biotite and hornblende are absent in the gneisses in the southernmost third of the block; these have been extensively melted and contain disrupted rafts of migmatite. In thin-section, the partially melted gneiss contains restitic feldspar and quartz grains divided by parallel-sided seams of fine-grained granophyre. Dendritic overgrowths of restitic feldspar grains attest to rapid cooling rates. Larger pockets of melt have solidified as euhedral feldspar grains enclosed by oikocrystic quartz. Quartz paramorphs after tridymite are either absent or too poorly developed to be definitively identified.

Further evidence of an increase in metamorphic grade towards the south is provided by the numerous basaltic dykes cutting the Lewisian block. Those in the north have chilled margins, while those in the south generally have no chills and are cut by coarse-grained veins of felsic material sourced from the surrounding gneiss.

In the vicinity of [NM 40330 93462], at the southwest of the Lewisian block, the partially melted gneiss contains a variety of rounded clasts of mafic and ultramafic cumulates. One block of peridotite contains rounded cumulus olivine grains ( $95 \%$ by volume) of composition $\mathrm{Fo}_{83.8-84.4}$ with subhedral cumulus $\mathrm{Cr}$ spinel set in diopsidic pyroxene oikocrysts ( $\mathrm{Mg}$ no. 84.8-85.8) with some interstitial plagioclase $\left(\mathrm{An}_{77-82}\right)$. The more elongate olivine grains display a preferred orientation and comprise sub-grains consistent with a formation by intra-crystalline deformation during compaction.

The isograds in the Lewisian block run approximately parallel to the short axis of the block, whereas the isograds in the overall aureole associated with the Eastern Layered Intrusion (ELI, Fig. 1) run parallel to the long axis of the block. While the isograds have not been mapped further south than the Allt nam $\mathrm{Ba}$ (Holness \& Isherwood, 2003), extrapolation to Beinn nan Stac suggests that temperatures in the main aureole, associated with the Eastern Layered Intrusion (Fig. 1), were much lower than that needed to begin melting (cf. Thompson, 1981). The lack of correspondence of metamorphic grade in the gneiss block with the isograds in the main aureole suggests that this faultbounded block of Lewisian gneiss was metamorphosed during an early high-temperature event. This event would have pre-dated both the emplacement of the gneiss at its current position in the Main Ring Fault and the emplacement of the Eastern Layered Intrusion.

\section{Compositional analysis of the Am Màm breccia component parts}

\section{6.a. Analytical procedures}

A representative selection of the component parts of the Am Màm intrusion breccia were analysed for major and trace elements. These parts included the matrix of the intrusion breccia from the Northern Marginal Zone and the Southern Mountains Zone, lobate mafic inclusions, and the marginal rhyodacite and mafic rocks (see Table 1). REE and isotopic ( $\mathrm{Sr}, \mathrm{Nd}$ ) data from some samples in Table 1, as well as from a larger selection of Rum rocks that includes the early coarse gabbro within the Am Màm intrusion, are presented in Meyer et al. (2009, this issue), dealing in greater detail with magmatic evolution on Rum.

Most analyses, summarized in Table 1, were determined from glass discs and pressed powders on a Spectro X-Lab EDP XRF at the University of St Andrews, Scotland (www.st-andrews.ac.uk/gg/). The other samples were analysed at the Centre d'Analyses Minérale, University of Lausanne, Switzerland, using a Phillips PW 1400. All analyses were performed with a Rh tube, and calibration was performed using international geological reference samples (see Chew, Graham \& Whitehouse, 2007, for analytical details).

\section{6.b. XRF results}

On a total alkali v. silica classification diagram, the matrix of the Am Màm is dacitic (63.57-64.06 wt \% $\mathrm{SiO}_{2}$ ). The mafic inclusions show a larger spread in chemical composition (51.19-56.09 wt \% $\mathrm{SiO}_{2}$ ), from basaltic andesite to trachyandesite (Fig. 8). Mafic inclusions found within the (Northern Marginal Zone) rhyodacites show a compositional range from 51.55 to $58.61 \mathrm{wt} \% \mathrm{SiO}_{2}$ (Troll, Donaldson \& Emeleus, 2004). Inclusions from within the Am Màm intrusion breccia plot close to the rhyodacite-hosted inclusions. The mafic margins to both the Am Màm intrusion breccia and the intrusive rhyodacite have a very similar compositional range (51.89-53.13 wt \% $\mathrm{SiO}_{2}$ ) and they plot close to the mafic inclusions found within both of these felsic rock types.

Data from the rhyodacites exhibit consistent geochemical trends and form a relatively tight compositional cluster $\left(69.63-71.37 \mathrm{wt} \% \mathrm{SiO}_{2}\right.$ ) (Troll, Donaldson \& Emeleus, 2004). Data from the Western 
Table 1. Representative major (wt \%), trace element (ppm) concentrations for the Am Màm-type intrusion breccia and rhyodacite mafic margins

\begin{tabular}{|c|c|c|c|c|c|c|c|c|c|c|c|c|c|c|}
\hline \multirow{2}{*}{$\begin{array}{l}\text { Rock type } \\
\text { Location }\end{array}$} & \multicolumn{4}{|c|}{ Am Màm matrix } & \multicolumn{3}{|c|}{ Mafic inclusions } & \multicolumn{4}{|c|}{ Rhyodacite margins } & \multicolumn{3}{|c|}{$\begin{array}{l}\text { Basalt margins (Am Màm and } \\
\text { rhyodacite) }\end{array}$} \\
\hline & NMZ & NMZ & SMZ & SMZ & SMZ & SMZ & SMZ & NMZ & NMZ & SMZ & SMZ & NMZ & NMZ & SMZ \\
\hline GPS [NM] & 38755 & 38739 & 39333 & 39326 & 39326 & 39326 & 39366 & 38813 & 38811 & 39326 & 38511 & 38811 & 38220 & 38455 \\
\hline (UK grid) & 98604 & 98598 & 93069 & 93104 & 93104 & 93104 & 92977 & 98561 & 98560 & 93104 & 92482 & 98560 & 98449 & 93551 \\
\hline Sample & AM-06 & AM-07 & AM-13\# & AM-14\# & ME-8\# & ME-10\# & ME-11\# & RDPM-1 & RDPM-2 & RDPM-3 & AMG-1 & AMBM & RDPBM & RDPBM \\
\hline $\mathrm{SiO}_{2}$ & 64.06 & 63.85 & 63.83 & 63.57 & 56.09 & 50.04 & 51.19 & 74.47 & 74.79 & 63.48 & 68.10 & 53.13 & 51.89 & 51.94 \\
\hline $\mathrm{TiO}_{2}$ & 0.65 & 0.66 & 0.69 & 0.91 & 0.97 & 2.02 & 1.93 & 0.55 & 0.49 & 0.69 & 0.65 & 2.14 & 1.99 & 2.04 \\
\hline $\mathrm{Al}_{2} \mathrm{O}_{3}$ & 16.51 & 16.55 & 16.08 & 14.31 & 18.16 & 13.94 & 13.45 & 12.48 & 12.57 & 15.79 & 13.74 & 13.57 & 13.45 & 13.33 \\
\hline $\mathrm{FeO}$ & 5.56 & 5.47 & 5.44 & 7.15 & 6.96 & 13.46 & 12.89 & 3.95 & 3.76 & 5.88 & 4.97 & 13.59 & 12.39 & 13.74 \\
\hline $\mathrm{MnO}$ & 0.09 & 0.08 & 0.10 & 0.13 & 0.09 & 0.24 & 0.21 & 0.07 & 0.06 & 0.10 & 0.07 & 0.24 & 0.21 & 0.21 \\
\hline $\mathrm{MgO}$ & 2.14 & 2.05 & 1.89 & 2.01 & 3.85 & 5.03 & 4.66 & 0.38 & 0.37 & 2.33 & 2.48 & 4.41 & 4.76 & 4.84 \\
\hline $\mathrm{CaO}$ & 2.84 & 3.02 & 3.19 & 3.52 & 2.46 & 9.64 & 9.38 & 1.09 & 1.08 & 3.94 & 3.04 & 7.91 & 9.18 & 8.19 \\
\hline $\mathrm{K}_{2} \mathrm{O}$ & 2.91 & 2.86 & 3.88 & 3.44 & 3.25 & 2.74 & 2.70 & 3.35 & 3.46 & 3.64 & 2.19 & 0.92 & 2.70 & 0.87 \\
\hline $\mathrm{Na}_{2} \mathrm{O}$ & 3.42 & 3.64 & 3.08 & 2.78 & 6.07 & 0.68 & 1.29 & 2.95 & 2.68 & 2.70 & 3.10 & 2.68 & 1.29 & 2.88 \\
\hline $\mathrm{P}_{2} \mathrm{O}_{5}$ & 0.21 & 0.21 & 0.37 & 0.29 & 0.44 & 0.28 & 0.39 & 0.12 & 0.09 & 0.25 & 0.14 & 0.30 & 0.19 & 0.28 \\
\hline Total & 98.39 & 98.39 & 98.55 & 98.09 & 98.35 & 98.06 & 98.07 & 99.41 & 99.35 & 98.81 & 98.48 & 98.89 & 98.03 & 98.32 \\
\hline $\mathrm{Nb}$ & 9 & 9 & 8 & 11 & 14 & 6 & 8 & 11 & 10 & 3 & 9 & 5 & 4 & 4 \\
\hline $\mathrm{Zr}$ & 193 & 192 & 207 & 226 & 64 & 150 & 173 & 321 & 320 & 165 & 181 & 162 & 158 & 157 \\
\hline Y & 23 & 23 & 22 & 29 & 16 & 25 & 28 & 32 & 31 & 10 & 18 & 31 & 31 & 30 \\
\hline $\mathrm{Sr}$ & 475 & 502 & 506 & 351 & 417 & 279 & 256 & 189 & 177 & 309 & 302 & 299 & 274 & 272 \\
\hline $\mathrm{U}$ & $<1$ & 1 & $<2$ & 2 & 2 & 2 & 2 & 1 & 1 & 2 & 1 & 1 & 1 & 1 \\
\hline $\mathrm{Rb}$ & 85 & 82 & 71 & 60 & 119 & 23 & 41 & 98 & 98 & 39 & 96 & 27 & 38 & 18 \\
\hline Th & 7 & 8 & 5 & 6 & 10 & 3 & 4 & 7 & 7 & 4 & 5 & 4 & 4 & 3 \\
\hline $\mathrm{Pb}$ & 20 & 14 & 15 & 14 & 12 & 6 & 9 & 11 & 9 & 2 & 6 & 5 & 20 & 3 \\
\hline $\mathrm{Ga}$ & 18 & 19 & 19 & 20 & - & 19 & 17 & 17 & 17 & 14 & 18 & 20 & 19 & 22 \\
\hline $\mathrm{Zn}$ & 242 & 69 & 71 & 93 & 73 & 101 & 94 & 55 & 216 & 56 & 286 & 376 & 538 & 521 \\
\hline $\mathrm{Cu}$ & 83 & 14 & 25 & 21 & 5 & 95 & 68 & 28 & 75 & 20 & 63 & 169 & 211 & 197 \\
\hline $\mathrm{Ni}$ & 21 & 16 & 23 & 1734 & 22 & 37 & 34 & 3 & 3 & 13 & 17 & 24 & 28 & 29 \\
\hline $\mathrm{Cr}$ & 70 & 87 & 67 & 379 & 50 & 87 & 80 & 3 & 3 & 52 & 94 & 3 & 2 & 15 \\
\hline V & 91 & 86 & 79 & 132 & 66 & 418 & 347 & 4 & 4 & 97 & 104 & 513 & 548 & 513 \\
\hline $\mathrm{Ce}$ & 69 & 68 & 105 & 87 & 61 & 30 & 39 & 97 & 94 & 87 & 61 & 41 & 40 & 35 \\
\hline $\mathrm{Nd}$ & 36 & 38 & 35 & 34 & 35 & 16 & 21 & 46 & 42 & 34 & 26 & 17 & 23 & 21 \\
\hline $\mathrm{Ba}$ & 977 & 900 & 1146 & 738 & 308 & 197 & 226 & 1013 & 1022 & 452 & 580 & 332 & 238 & 246 \\
\hline $\mathrm{La}$ & 27 & 27 & 53 & 30 & 34 & 16 & 19 & 45 & 43 & 58 & 27 & 16 & 15 & 12 \\
\hline
\end{tabular}

\#- determined at the Centre d'Analyses Minérale, University of Lausanne, Switzerland 


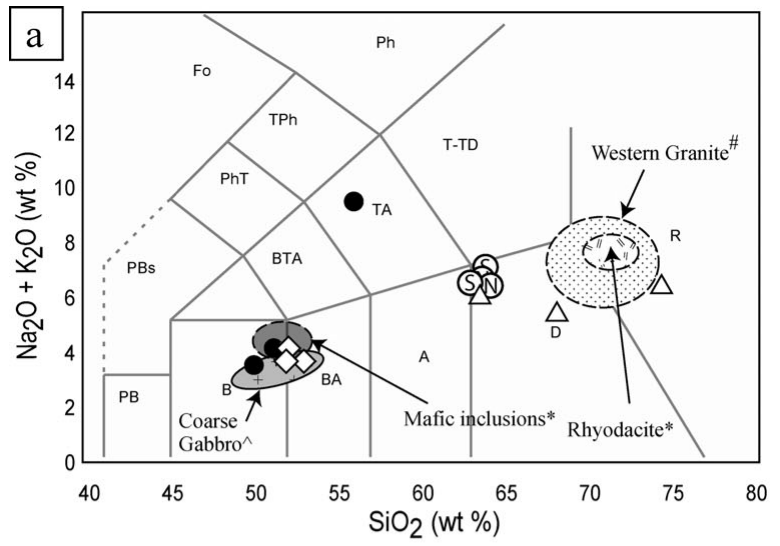

Mafic inclusions within the Am Màm-type intrusion

$\diamond$ Mafic margin to the Am Màm-type intrusion and rhyodacite

$\triangle$ Felsic margin to the Am Màm-type intrusion

(1) Am Màm-type intrusion matrix, \# data from Emeleus, (1997) (5) N=NMZ, S = SMZ $\quad \begin{aligned} & \text { * data from Troll, Donaldson \& Emeleus, (2004 } \\ & \wedge \text { data from Nicoll unpublished }\end{aligned}$
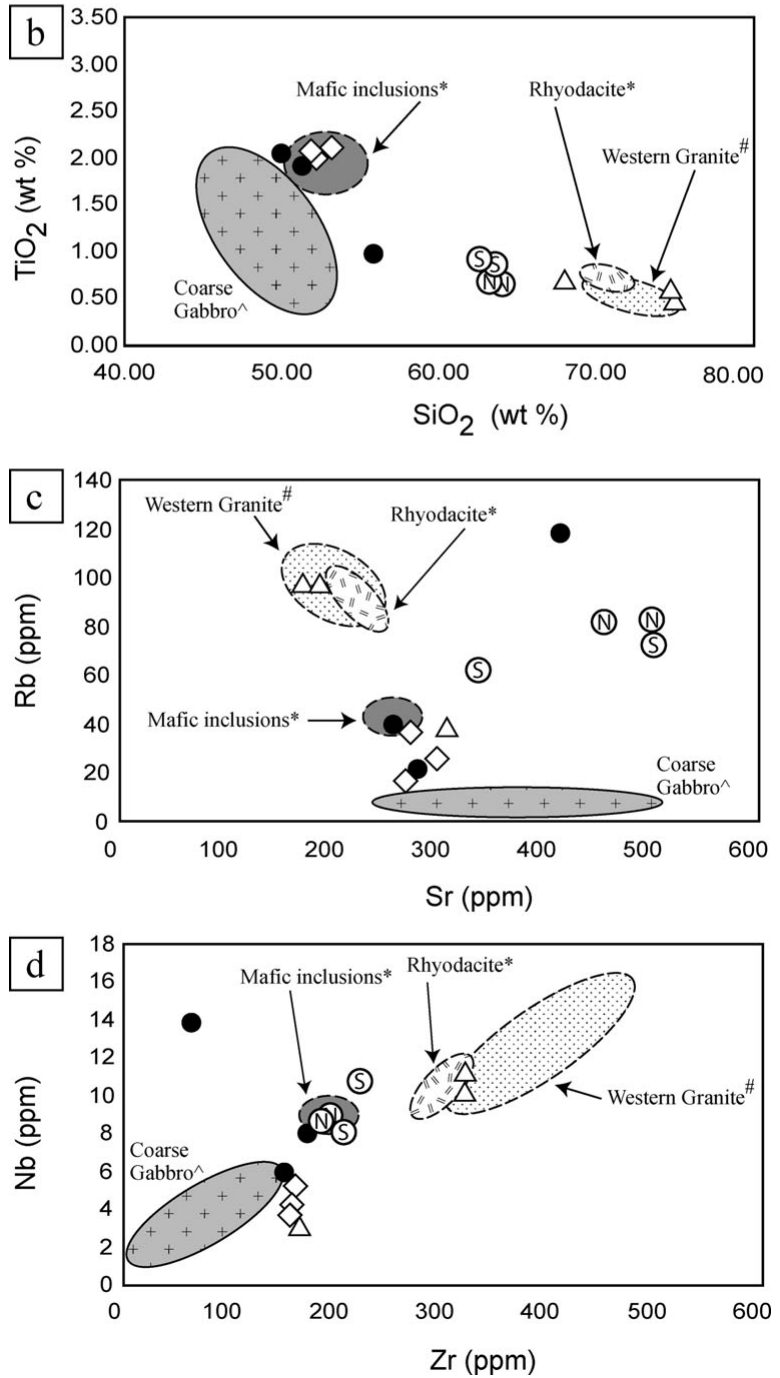

Figure 8. (a) Total alkali v. silica diagram for the component parts of the Am Màm intrusion breccia. (b-d) Representative major and trace element plots.

Granite (Emeleus, 1997) show considerable variation but all plot in the rhyodacite to rhyolite fields $(68.50$ $\left.72.00 \mathrm{wt} \% \mathrm{SiO}_{2}\right)$. The rhyodacite margins of the Am Màm intrusion breccia show the most variable compositional range in the felsic spectrum (63.4874.79 wt $\% \mathrm{SiO}_{2}$ ), with the samples from the Northern Marginal Zone representing the most evolved felsic material found to date on Rum (Fig. 8, Table 1). Major and trace element plots are shown to place the Am Màm intrusion with reference to the other felsic rocks on Rum (Fig. 8). Data for the early coarse gabbros within the Am Màm intrusion breccia are also shown in Figure 8 (G. R. Nicoll, unpub. Ph.D. thesis, Univ. Dublin, 2009); see Meyer et al. (2009, this issue) for a more detailed comparison of the evolution and relationship of these rocks.

\section{Discussion}

7.a. Am Màm intrusion breccia: structure, timing of emplacement and relationship to other felsic rocks on Rum

Am Màm breccia was previously considered to occur only in the Northern Marginal Zone, and little was known about its structure. The breccia was thought to have been emplaced earlier than the other stage 1 felsic rocks, as well as the caldera in-fill sedimentary breccias and sandstones (Emeleus, 1997; Troll, Emeleus \& Donaldson, 2000). Our detailed remapping of the Am Màm breccia and intrusive tuffs shows that the Am Màm intrusion breccia was emplaced in both the Northern Marginal Zone and the Southern Mountains Zone. Moreover, the field relationships described herein indicate that basalt, non-foliated rhyodacite, Am Màm intrusion matrix and foliated rhyodacite were intruded in close succession to form sheet-like (or even partly funnel-like) composite intrusions (also see Holohan et al. 2009, this issue).

The field evidence shows that emplacement of the Am Màm intrusion breccia occurred much later than previously thought, and may even have taken place in close association with major pyroclastic eruptions and caldera formation. First, emplacement of the composite Am Màm intrusions demonstrably postdated the lowermost sections of the caldera infill (Coire Dubh-type breccias). Second, in the Southern Mountains Zone, the emplacement of the Am Màm intrusion breccia either post-dated, or was synchronous with, movement on the inner strand of the Main Ring Fault. This inner fault strand accommodated caldera subsidence (see Holohan et al. 2009, this issue). Third, emplacement of the Am Màm intrusion breccias was temporally and spatially associated with intrusion of foliated (fiamme-bearing) rhyodacite in both marginal zones. In the Northern Marginal Zone, the composite intrusion of which the Am Màm breccia is a part, links into what is interpreted as a major rhyodacitic ignimbrite feeder system (cf. Troll, Emeleus \& Donaldson, 2000). A similar relationship may exist between the Am Màm-type breccia and a major ignimbrite feeder system in the Southern Mountains Zone (see Holohan et al. 2009, this issue).

In both the Northern Marginal Zone and the Southern Mountains Zone, emplacement of the Am 
Màm intrusion breccia seems to have been strongly controlled by faults, especially the Main Ring Fault (Fig. 3a, b). The intrusion of felsic and mafic magmas into this zone of fractured and shattered rock (gneiss and Torridonian sandstone) may account for the quantity and composition of some of the clast types within the Am Màm intrusion breccias, as the majority of clasts are sourced locally. The presence, however, of entrained exotic coarse gabbros and thermally altered gneisses may point to substantial exhumation and some degree of magmatic transport to account for these allochthonous-entrained clasts.

The geochemical data (both major and trace element) of this study (Fig. 8) and rare earth element and isotopic data (Meyer et al. 2009, this issue) support a close genetic connection of the Am Màm intrusion matrix and the rhyodacites, as inferred from the revised field relationships. These rocks form a geochemical suite consistent with mixing of variable amounts of mafic magma with Lewisian-derived felsic partial melts (Fig. 8; see Meyer et al. 2009, this issue, for corresponding isotopic data). Evidence for early felsic melt generation and migration is preserved in the Lewisian gneiss blocks contained in and associated with the Am Màm intrusions. This provides a unique record of early anatectic processes on the Isle of Rum and may hold a key in investigating the origin of felsic melts in the North Atlantic Igneous Province.

\section{7.b. Earliest mafic magma and crustal partial melting}

Interpretation of textures from the solidified melt pockets within the Lewisian fragments exposed along the course of the Main Ring Fault are of critical importance. Textures formed during the solidification of migmatites are a function of cooling rate and melt pool size (Holness \& Sawyer, 2008). Shorter times for solidification result in fine granophyric intergrowths, while igneous-type textures (euhedral grains enclosed by an oikocryst of another phase) require longer solidification times. Granophyre is rare or absent in rocks solidified at pressures of more than a few kilobars; instead these develop coarse igneous-type textures.

Previous work on the Lewisian gneisses of Rum has shown that solidification textures include granophyric rims separating restitic quartz and feldspar, incipient coarse granophyre, 'string-of-beads texture' and pools of euhedral plagioclase enclosed by quartz (Holness \& Isherwood, 2003). Granophyre is absent from the large area of uplifted gneiss exposed at Fiachanis in the southwest of Rum, but it is common in the gneisses found at Priomh Lochs in the Northern Marginal Zone (Fig. 1; also see Emeleus, 1997). Tridymite is locally present in the granophyres that have developed in the gneiss at Priomh Lochs, which led Holness \& Isherwood (2003) to suggest that the Priomh Lochs gneisses were metamorphosed at considerably shallower depths than the gneisses found at Fiachanis in the southwest of Rum.
The fragments of Lewisian gneiss entrained in the xenolithic dolerite and the Am Màm intrusion breccia contain tridymite. The fine-grained granophyre that developed in the melt rims separating quartz and feldspar grains in these xenoliths implies that the melt solidified rapidly at shallow levels, consistent with exhumation in intrusions that exploit the Main Ring Fault. The textures of solidified melt in the faultbounded gneiss block at Beinn nan Stac are highly reminiscent of those gneissic xenoliths, although they contain coarser-grained feldspar. We interpret this block of Lewisian to have been tectonically uplifted and possibly entrained by a felsic, crustal-derived, liquid during a time of significant movement on the Main Ring Fault. It contained partial melt during entrainment and solidified relatively rapidly at, or close to, the present level of exposure.

Importantly, the presence of the peridotite, gabbroic and dunite xenoliths as well as lobate mafic inclusions within the Am Màm intrusion breccia provides evidence for the presence of a highly differentiated body of mafic melt in the crust beneath Rum prior to caldera formation and the onset of major explosive volcanism. Isotopic data indicate the early gabbroic rocks assimilated 10-20\% Lewisian gneiss (see Meyer et al. 2009, this issue). They are thus compositionally very different from the intrusive gabbros of the Eastern Layered Intrusion and from the source magmas believed to have fed the layered intrusions (e.g. Upton et al. 2002). This early mafic magma body presumably had a well-established reservoir system at an early stage in the Paleocene igneous evolution of the Rum complex, and underwent fractionation to form peridotitic and gabbroic cumulates. The crystal mush that developed on the floor of this early chamber was apparently sufficiently thick to induce compaction of the olivine grains. Similarities of grain-size and texture between the peridotite xenoliths and the peridotite horizons of the Eastern Layered Intrusion suggest that this early mafic body may have been of a similar size to the later layered intrusion.

The large blocks of coarse gabbro entrained within the Am Màm intrusion breccia, such as at Loch Gainmhich, provide further evidence of a large, welldeveloped and deep-seated mafic magma body which pre-dated caldera collapse and the eruption of the early felsic suite. The median clinopyroxene-plagioclaseplagioclase dihedral angle $\left(109^{\circ}\right)$ in this gabbro is amongst the highest measured on Rum, considerably higher than the median values of $\sim 90^{\circ}$ typical of gabbroic allivalites from the Eastern Layered Intrusion (Holness, 2005). This value is also significantly higher, for example, than those of the Skaergaard Layered Series, which are generally below $103^{\circ}$ and, for gabbros containing cumulus apatite, are of the order of $80^{\circ}$ (Holness et al. 2007). In order for an evolved and relatively cool gabbro to undergo such significant textural maturation, it must have cooled considerably slower than the Skaergaard did (cf. Holness, Cheadle $\&$ McKenzie, 2005). Therefore, the early gabbro body 
on Rum was either larger than the Skaergaard intrusion $(8 \times 11 \times 4 \mathrm{~km}$ : Nielsen, 2004$)$ or was a smaller body crystallizing deeper than $2-3 \mathrm{~km}$ (Larsen \& Tegner, 2006).

Textures in the Lewisian gneiss in contact with the coarse gabbro block at Loch Gainmhich are consistent with contact metamorphic anatexis and solidification at depth. The solidification textures do not include granophyre, and have more in common with the gneisses of the Fiachanis area in southwest Rum than with the Priomh Lochs gneiss in the Northern Marginal Zone. The heat source for metamorphism of the Loch Gainmhich gneiss block must therefore have been a large, deep, body of mafic magma, now only represented by the coarse gabbro blocks and peridotite clasts within the Am Màm intrusion. This mafic body must have solidified before entrainment by the Am Màm magma.

The implications of the Loch Gainmhich observations are that the bulk of the anatexis observed in the gneiss at the Fiachanis area must also have occurred at depth. Bailey (1945) suggested at least $1.7 \mathrm{~km}$ of exhumation for these rocks, which seems consistent with our observations. In contrast, the Priomh Lochs anatexis occurred close to the present level of exposure, much closer to the palaeo-surface (Holness \& Isherwood, 2003).

The large blocks and numerous smaller clasts of coarse gabbro and gneiss represent relicts of an early magma reservoir that interacted at depth $(>2$ $3 \mathrm{~km}$ ) with crustal rocks to produce crustal partial melts. These 'megablocks' and clasts are therefore not in their original position. Density and viscosity calculations (after Dingwell \& Webb, 1989; Pinkerton \& Stevenson, 1992) suggest that larger clasts within the Am Màm intrusion breccia (e.g. larger than 1-2 m) would not have been buoyant within stationary dacitic magmas. We propose a combination of Paleocene tectonic uplift and erosion, followed by subsequent entrainment and transportation of these large xenolithic blocks within rising mixed mafic-felsic intrusions, to explain the present location of the coarse gabbro blocks and thermally altered gneisses within the ring fault. Intrusion occurred during large-scale caldera collapse and accompanying, piston-like, forceful injection of liquid and gaseous/volatile components from the underlying chamber system and its contact aureole into the opening ring fissure (cf. Garner \& McPhie, 1999; Kennedy, Jellinek \& Stix, 2008).

\section{Conclusions}

The Am Màm intrusion breccia in the Northern Marginal Zone represents a lithic-rich, intermediate (andesite/dacite) product of partial melting of Lewisian gneiss caused by intruding mafic magmas. Geochemical evidence demonstrates that the Am Màm intrusion matrix is genetically related to the other felsic magmas on Rum.
The Am Màm breccia is not, as previously thought, the earliest lithological unit to be intruded during the felsic phase. Rather, its emplacement was coeval with the main phase of rhyodacite intrusion and eruption and therefore with caldera collapse. The rocks in the Southern Mountains Zone, formerly classified as tuffisites or intrusive tuffs, comprise a lithologically, temporally and structurally identical intrusive suite, here classified as part of the Am Màm intrusion breccia; we propose that they are lateral equivalents of those in the Northern Marginal Zone

Evidence of the earliest mafic magmas that led to large-scale crustal anatexis on Rum is plentiful within the Am Màm-type intrusion breccias. Coarse gabbro blocks within the Am Màm intrusion breccia preserve a unique window into a large and deep-seated mafic body that initiated felsic volcanic activity on Rum during the Paleocene. To bring these coarse gabbros to their current stratigraphic level, considerable exhumation of these 'megablocks' entrained within the early felsic intrusions is proposed. This event was most probably associated with large-scale caldera collapse that injected parts of the chamber aureole into the evolving ring fault system.

Acknowledgements. We are most grateful to Scottish Natural Heritage (SNH) and Ed Hawan (Rum Reserve Manager) for sampling permission and logistical assistance while on the island. G. R. Nicoll and V. R. Troll were supported by a Science Foundation Ireland grant. This manuscript benefited enormously from constructive reviews by R. Wilson and B. Upton.

\section{References}

BAILEY, E. B. 1945. Tertiary igneous tectonics of Rhum (Inner Hebrides). Quarterly Journal of the Geological Society of London 100, 165-91.

BLACK, G. P. 1954. The acid rocks of western Rhum. Geological Magazine 91, 257-72.

Brown, D. J., Holohan, E. P. \& Bell, B. R. 2009. Sedimentary and volcano-tectonic processes in the British Paleocene Igneous Province: a review. Geological Magazine 146, 326-52.

Chambers, L. M., Pringle, M. S. \& Parrish, R. R. 2005. Rapid formation of the Small Isles Tertiary centre constrained by precise ${ }^{40} \mathrm{Ar} /{ }^{39} \mathrm{Ar}$ and $\mathrm{U}-\mathrm{Pb}$ ages. Lithos 79, 367-84.

Chew, D. M., Graham, J. R. \& Whitehouse, M. J. 2007. U-Pb zircon geochronology of plagiogranites from the Lough Nafooey (= Midland Valley) arc in western Ireland: constraints on the onset of the Grampian orogeny. Journal of the Geological Society, London 164, $747-50$.

Dingwell, D. B. \& WeBB, S. L. 1989. Structural relaxation in silicate melts and non-Newtonian melt rheology in geologic processes. Physics and Chemistry of Minerals 16, 508-16.

DunHAM, A. C. 1968. The felsites, granophyre, explosion breccias and tuffisites of the north eastern margin of the Tertiary igneous complex of Rhum, Inverness-shire. Quarterly Journal of the Geological Society of London 123, 327-52. 
Dunham, A. C. \& Thompson, R. N. 1967. The origin of granitic magma: Skye and Rhum. Journal of the Geological Society of Australia 14, 339-44.

EMELEUS, C. H. 1985. The Tertiary lavas and sediments of northwest Rhum, Inner Hebrides. Geological Magazine 122, 419-37.

EMELEUS, C. H. 1997. Geology of Rum and the adjacent islands. Memoirs of the British Geological Survey Sheet 60, (Scotland).

EMELEUS, C. H., WADSWORTH, W. J. \& SMITH, N. J. 1985. The early igneous and tectonic history of the Rhum Tertiary Volcanic Centre. Geological Magazine 122, 451-7.

GARner, A. \& MCPhie, J. 1999. Partially melted lithic megablocks in the Yardea Dacite, Gawler Range Volcanics, Australia: implications for eruption and emplacement mechanisms. Bulletin of Volcanology 61, 396-410.

HARKER, A. 1908. The geology of the Small Isles of Inverness shire. Memoirs of the Geological Survey, Scotland, Sheet 60, $210 \mathrm{pp}$.

HoLNESS, M. B. 2005. Spatial constraints on magma chamber replenishment events from textural observations of cumulates: the Rum Layered Intrusion, Scotland. Journal of Petrology 46, 1585-1601.

Holness, M. B., Cheadle, M. J. \& MCKenzie, D. P. 2005. On the use of changes in dihedral angle to decode late-stage textural evolution in cumulates. Journal of Petrology 46, 1565-83.

Holness, M. B. \& IsHerwood, C. E. 2003. The aureole of the Rum Tertiary Igneous Complex, Scotland. Journal of the Geological Society, London 160, 15-27.

HolNESS, M. B. \& SAWYER, E. W. 2008. On the pseudomorphing of melt-filled pores in migmatites. Journal of Petrology 49, 1343-63.

Holness, M. B., Tegner, C., Nielsen, T. F. D., Stripp, G. \& MORSE, S. A. 2007. A textural record of solidification and cooling in the Skaergaard Intrusion, East Greenland. Journal of Petrology 48, 2539-77.

Holohan, E. P., Troll, V. R., ERrington, M., DonAldson, C. H., Nicoll, G. R. \& Emeleus, C. H. 2009. The Southern Mountains Zone, Isle of Rum, Scotland: volcanic and sedimentary processes upon an uplifted and subsided magma chamber roof. Geological Magazine 146, 400-18.

Hughes, C. J. 1960. The Southern Mountains Igneous Complex, Isle of Rhum. Quarterly Journal of the Geological Society of London 116, 111-38.

Kennedy, B. M., JellineK, M. J. \& Stix, J. 2008. Coupled caldera subsidence and stirring inferred from analogue models. Nature Geoscience 1, 385-9.

LARSEN, R. H. \& TEGNER, C. 2006. Pressure conditions for the solidification of the Skaergaard intrusion: eruption of East Greenland flood basalts in less than 300,000 years. Lithos 92, 181-97.

Meyer, R., Nicoll, G. R., Hertogen, J., Troll, V. R., Ellam, R. M. \& EMELEUS, C. H. 2009. Trace element and isotope constraints on crustal anatexis by upwelling mantle melts in the North Atlantic Igneous Province: an example from the Isle of Rum, NW Scotland. Geological Magazine 146, 382-99.

NiELSEN, T. F. D. 2004. The shape and volume of the Skaergaard Intrusion, East Greenland: implications for mass balance and bulk composition. Journal of Petrology 45, 507-30.

Pinkerton, H. \& SteVEnson, R. J. 1992. Methods of determining the rheological properties of magmas at sub-liquidus temperatures. Journal of Volcanology and Geothermal Research 53, 47-66.

Thompson, R. N. 1981. Thermal aspects of the origin of Hebridean Tertiary acid magmas. I. An experimental study of partial fusion of Lewisian gneisses and Torridonian sediments. Mineralogical Magazine 44, 161-70.

Troll, V. R., Donaldson, C. H. \& Emeleus, C. H. 2004. Pre-eruptive magma mixing in ash-flow deposits of the Tertiary Rum igneous centre, Scotland. Contributions to Mineralogy and Petrology 147, 72239.

Troll, V. R., Emeleus, C. H. \& Donaldson, C. H. 2000. Caldera formation in the Rum Central Igneous Complex, Scotland. Bulletin of Volcanology 62, 30117.

Troll, V. R., Nicoll, G. R., Emeleus, C. H. \& Donaldson, C. H. 2008. Dating the onset of volcanism at the Rum Igneous Centre, NW Scotland. Journal of the Geological Society 165, 651-9.

Upton, B. G. J., McClurg, J., SkovgaArd, A. C., Kirstein, L., Cheadle, M., Emeleus, C. H., Wadsworth, W. J. \& FAlLICK, A. E. 2002. Picritic magmas and the Rum ultramafic complex, Scotland. Geological Magazine 139, 437-52.

WAGer, L. R. \& Brown, G. M. 1951. A note on rhythmic layering in the ultrabasic rocks of Rhum. Geological Magazine 88, 166-8.

WAGER, L. R. \& BROWN, G. M. 1968. Layered igneous rocks. Edinburgh: Oliver and Boyd, $588 \mathrm{pp}$.

Walsh, J. N., Beckinsale, R. D., SKelhorm, R. R. \& THORPE, R. S. 1979. Geochemistry and petrogenesis of Tertiary granitic rocks from the Islend of Mull, northwest Scotland. Contributions to Mineralogy and Petrology 71, 99-116.

Williams, P. J. 1985. Pyroclastic rocks in the Cnapan Breaca felsite, Rhum. Geological Magazine 122, 44750 . 